\title{
THE ROLE OF EFFICIENCY MEDIATION IN THE EFFECT OF BANKS SIZE ON BANK PROFITABILITY IN INDONESIA
}

\author{
Andi Ruslan ${ }^{1}$ \\ Institute for Islam Studies (IAIN) Bone, Watampone, Indonesia \\ Cepi Pahlevi, Syamsu Alam, Mursalim Nohong \\ Hasanuddin University Makassar, Indonesia
}

\begin{abstract}
The purpose of this study was to analyze the mediating role of bank efficiency in the effect of bank size on bank profitability. The research sample is 25 banks that have a minimum core capital of $R p$. 5,000,Ooo,ooo,ooo and publish financial statements in full during 2010-2017. The data analysis technique in this study is path analysis (path analysis) with the help of AMOS software (Analysis of Moment Structure). The results of the study found that; 1) bank size has a positive and significant effect on bank efficiency; 2) bank size has a positive and not significant effect on bank profitability; 3) bank efficiency has a positive and significant effect on bank profitability. 4) bank efficiency is able to mediate the effect of bank size on bank profitability.
\end{abstract}

Keywords: Bank Size, Efficiency, Profitability, Indonesia 


\section{INTRODUCTION}

The banking industry in Indonesia continues to develop, this can be seen from the increase in the number of banks and the growth in the number of banking assets. The banking industry has a very important role in the financial system in Indonesia by controlling the market share of the largest financial assets in the economy. By looking at the Indonesian Financial System Statistics (SSKI) the banking industry has a market share of 77.22\% in April 2019 (Bank Indonesia, 2019). The development of banking assets in Indonesia can be seen in table 1 as follows:

Table 1 Development of Indonesian Banking Assets

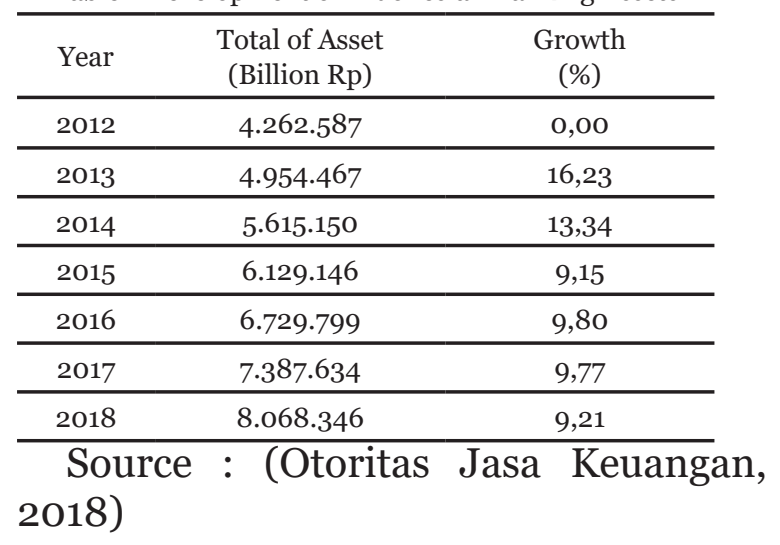

The table above shows that Indonesian banking assets continue to increase each year, where the highest increase occurred in 2013 with a growth of $16.23 \%$ from the previous year. With this achievement, it will support bank activities in achieving good performance, especially profitability performance.

One of the indicators for assessing the financial performance of a bank is to look at the level of profitability. The main objective of bank operations is to achieve maximum levels of profitability (Vernanda \& Widyarti, 2016) Profitability is the ability of banks to generate or earn profits effectively and efficiently. To achieve an effective and efficient financial system, the banking sector must increase profitability by increasing sources of funds from the community and channeling it to sectors in need in the economy as well as improving the quality of financial services for its customers. (Menicucci \& Paolucci, 2016)

Bank profitability is influenced by many factors, both external and internal factors. Some previous studies found that one of the factors that determine bank profitability is the efficiency factor of bank banks. Where bank efficiency is largely determined by the bank's internal characteristics such as bank size. Several previous studies (Petria, Capraru, \& Ihnatov, 2015) which examined the determinants of bank profitability in Europe, this study found that bank internal factors such as liquidity, credit risk, bank efficiency and external factors such as competition and economic growth had a significant effect on bank profitability in Europe. Furthermore, the size of the bank does not have a significant effect on bank profitability.

Other studies from (Martins, Serra, \& Stevenson, 2019) examined 108 banks in the United States, Britain, and Germany to examine the effect of bank characteristics and macroeconomic factors on bank profitability. This study found that bank-specific characteristics related to credit and liquidity risk, bank efficiency, total loan growth, opportunity costs, and implicit interest had a significant effect on bank profitability. Similarly, macroeconomic factors such as the Lerner Index, interest rate volatility and GDP also have a significant impact on profitability. Furthermore, the size of the bank does not have a significant effect on bank profitability.

Further research (Bouzgarrou, Jouida, \& Louhichi, 2017) examined 170 commercial banks in France for the period 2000-2012, finding that the dummy variables of foreign banks had a significant effect on bank profitability, 
variable liquidity, bank capital and macroeconomic variables such as economic growth and Fiscal freedom has a significant effect on bank profitability. The variable size of the bank does not have a significant effect on bank profitability.

Research (Vernanda \& Widyarti, 2016) which examines the effect of bank characteristics on bank profitability, the findings of this study are that simultaneous bank characteristics consisting of CAR, LDR, NPL, BOPO, and Size have a significant effect on bank profitability. Partially the efficiency ratio (BOPO) has the biggest influence on bank profitability and bank size does not have a significant effect on bank profitability. While research (Perwitaningtyas \& Pangestuti, 2015) which examines the factors that affect banking efficiency in Indonesia, found that the size factor, bank type, and CAR have a significant influence on banking efficiency, while the LDR and NPL do not affect banking efficiency.

Some of these studies indicate that bank size as measured by bank asset ownership does not have a significant effect on bank profitability, it means that the greater the size of the bank does not guarantee that the bank gets high profitability. While bank efficiency has a significant effect on profitability, this indicates that with the achievement bank efficiency The purpose of this study is to obtain empirical evidence of the effect of bank size on bank efficiency and bank profitability and test the mediating role of bank efficiency in bank size influence on bank profitability.

\section{THEORETICAL BACKGROUND Profitability}

Profitability is the ability of a company to generate profits for a certain period. Profitability can also be interpreted as a specific measure of the performance of a bank which is the goal of company management by maximizing the value of the company in the eyes of shareholders, optimizing the return value in each company operation, and minimizing the level of risk. (Rima Yunita, 2014)

The bank's profitability ratio is a ratio that shows the bank's ability to earn profits/profits in a certain period. The bank's profitability ratio is the main ratio in the financial statements because profit/ profit is the final result to be achieved by each banking company (Marwansyah \& Setyaningsih, 2018)

The profitability ratio used in this study is the Return on Assets (ROA). Return on Assets (ROA) is one of the profitability ratios used to measure the effectiveness of a company in generating profits by utilizing the total assets it has. (Van Horne and Wachowicz, 2005)

Return on Assets (ROA) focuses on the company's ability to earn income in company operations. ROA is used to measure bank profitability because Bank Indonesia as a supervisor and supervisor of banks prioritizes the value of a bank's profitability as measured by assets whose funds are mostly from public savings funds. In addition, ROA is used to measure the effectiveness of the company in generating profits by utilizing the assets it has. (Rima Yunita, 2014)

\section{Economic Scale Theory (Economies of Scale)}

Economic scale (Economies of Scale) in economics, refers to the cost advantages associated with business expansion. According to Gozali (2009), (Vernanda \& Widyarti, 2016) economies of scale point to the low-cost benefits derived from the expansion of operational activities in a company and are one way to achieve low-cost advantages in order to create competitive advantage. Economies of scale can be obtained from the development process and work efficiency in operational activities 
in all departments in the company. In addition, companies of various sizes can enjoy economies of scale benefits during the scale of production is increased.

\section{Bank Size Influence on Efficiency (BOPO)}

Size of a bank is one of the characteristics of abankwhich is generally a determinant of banking efficiency. First, if the size of the bank is positively related to market strength, then a larger bank will have lower input costs. Second, the possibility of increasing the return to scale is a situation where the input/ output ratio decreases with increasing firms. (Perwitaningtyas \& Pangestuti, 2015), (Yusniar, 2011), (Banna, Ahmad, \& Koh, 2017), stating that size has a significant effect on banking efficiency.

Hypothesis 1: Bank size has a negative influence on bank efficiency (BOPO)

Effect of Bank Size on Return on Assets (ROA)

In general, large companies that have large total assets are able to generate large profits. Larger banks measure assets more favorably than banks with small asset sizes, because larger bank sizes have a higher level of efficiency (Kosmidou \& Zopounidis, 2008). With large assets owned by banks, banks can have more productive assets than banks with smaller assets. The results of research (Menicucci \& Paolucci, 2016) find that bank size is one of the determinants of the level of profitability of banks in Europe. This is in line with research (Adelopo, Lloydking, \& Tauringana, 2018), which found that bank size had a positive effect on ROA. Other studies from (Petria et al., 2015), (Martins et al., 2019), (Bouzgarrou et al., 2017), (Vernanda \& Widyarti, 2016) found that size did not significantly influence bank profitability.

Hypothesis 2: Bank size has a positive influence on bank profitability (ROA)

The Effect of Efficiency on Profitability
BOPO has an influence on banking performance because it shows how much the bank can do efficiency on operational costs incurred (Vernanda \& Widyarti, 2016). Each increase in operational costs will result in a decrease in pretax profit and ultimately will reduce profit or profitability (ROA) of the bank concerned. The smaller the BOPO ratio, means the more efficient the operational costs incurred by the bank concerned so the greater the possibility for banks to get more profits. (Dendawijaya, 2003). (Vernanda \& Widyarti, 2016) (Petria et al., 2015), (Martins et al., 2019) found that BOPO had a negative and significant effect on bank profitability. This means that when the bank suppresses the BOPO ratio as small as possible the bank will increase the profits obtained by the bank.

Hypothesis 3: Efficiency has a negative influence on bank profitability (ROA)

\section{Banks Size Influence on Return} On Assets (ROA) through bank Efficiency

The greater the asset or size of a bank allows the bank to obtain large profits if the asset is managed well without causing a large problematic productive asset. With the management of good assets the bank will achieve bank efficiency levels

Hypothesis 4: Bank size has an indirect influence on bank profitability through bank efficiency

Based on the description above, the conceptual framework model in this study can be formed as follows:

Figure 1 Conceptual Framework

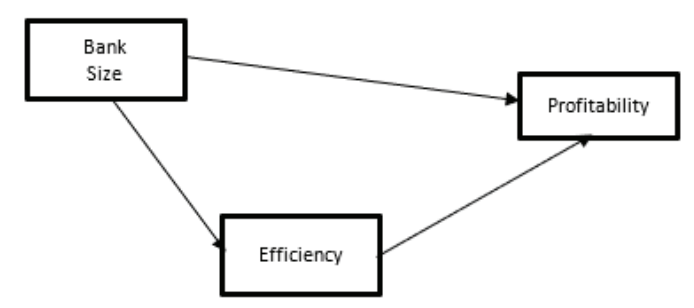




\section{METHODOLOGY}

\section{Population and Sample}

The population is the total number of groups of individuals or the overall object of research. The population in this study are all banks operating in Indonesia. The sample is part of the population that will be studied and is considered capable of representing the population.

The sampling technique in this study used a purposive sampling technique, which is sampling with certain considerations and criteria in accordance with the objectives of the study. The bank that will be used as the research sample is a Conventional Commercial Bank which has a core capital of at least Rp. $5,000,000,000,000$ or in the category of Group of Business Activities (BUKU) 3 and 4 and publish financial statements in full during 2011-2018. Based on the sampling criteria above, the banks that meet the requirements for use as samples in this study are 25 banks from 20102017.

\section{Types and Sources of Data}

types of data used in this study are documentary data in the form of financial statements of commercial bank groups in the categories of 3 and 4 Group of Business Activities in Indonesia for the period 2010-2017. While the data sources used in this study are secondary data in the form of figures in annual financial reports obtained from the Financial Services Authority (OJK), Bank Indonesia (BI) or from their respective Banks.

\section{Definition of Operational Variables}

Definition of operational variables aims to explain the meaning of the variables being studied, while the operational definitions of the research variables are described in table 2 as follows:
Tabel 2 Defenisi Oeparsional Variabel

\begin{tabular}{|c|c|c|c|}
\hline No. & Variable & Defenition & Measurement \\
\hline 1 & $\begin{array}{l}\text { Bank Size } \\
\quad(\mathrm{X} 1)\end{array}$ & $\begin{array}{l}\text { Total assets } \\
\text { owned by banks }\end{array}$ & Log Total Asset \\
\hline \multirow{2}{*}{2} & \multirow{2}{*}{$\begin{array}{l}\text { Efficiency } \\
\text { (Y1) }\end{array}$} & \multirow{2}{*}{$\begin{array}{l}\text { The ratio of } \\
\text { total operating } \\
\text { expenses to } \\
\text { total operating } \\
\text { income }\end{array}$} & \multirow{2}{*}{$\mathrm{BOPO}=$} \\
\hline & & & \\
\hline 3 & $\begin{array}{l}\text { Return on } \\
\text { Asset (Y2) }\end{array}$ & $\begin{array}{l}\text { The ratio used } \\
\text { to measure the } \\
\text { profitability of a } \\
\text { bank }\end{array}$ & $\mathrm{ROA}=\frac{\text { Earning Before Tax }}{\text { Total Asset }} \times 100 \%$ \\
\hline
\end{tabular}

\section{Data Analysis Techniques}

Based on the conceptual framework that was stated earlier, the method chosen for data analysis in this study is path analysis with the help of AMOS (software analysis of Moment Structure) Version 23.

\section{RESULT AND DISCUSSION Result}

Early research used 25 bank samples to form 200 data. But in processing the data found 10 data outliers that disrupt the normality of the data so that the data outliers are removed. So that the amount of observation data in this study becomes 190 data. Outlier data is data that has a unique value that is very different than other data. The unique data is in the form of extreme values both in the form of single variables and combination variables. Data outliers can cause bias in research, especially in the data normality test (Gunawan \& Sudaryanto, 2016), (Ghozali, 2013). This study requires the fulfillment of normality assumptions where distribution can be said to be normal if CR skewness and CR kurtosis are smaller than the critical table value \pm 2.58 with a significance level of 0.05 (P-Value 5\%). After the data outliers are removed, the data normality test in this study can be seen in the following table: 
Table 3 Assessment of normality

\begin{tabular}{lrrrrrr}
\hline Variable & $\min$ & $\max$ & skew & c.r. & $\begin{array}{c}\text { kur- } \\
\text { tosis }\end{array}$ & c.r. \\
\hline $\mathrm{X} 1$ & 6,566 & 9,032 &, 261 & 1,470 &,- 013 &,- 036 \\
\hline $\mathrm{Y} 1$ & 56,740 & 99,040 &,- 164 &,- 924 &,- 241 &,- 679 \\
\hline $\mathrm{Y} 2$ &, 090 & 5,340 &, 321 & 1,808 &,- 206 &,- 580 \\
\hline $\begin{array}{l}\text { Multi- } \\
\text { variate }\end{array}$ & & & & & 2,111 & 2,566 \\
\hline
\end{tabular}

Source: AMOS output

Univariate analysis in the table above, it is known that all variables have a $\mathrm{CR}$ value below \pm 2.58 . Thus it can be seen that univariate data distribution fulfills the normality assumption at the 0.05 significance level. Furthermore, multivariate testing revealed that $\mathrm{CR}$ crustosis of 2.566 was smaller than the critical value of the \pm 2.58 table. so that it can be concluded that multivariate data distribution is normal. Therefore the assumption of normality in this study has been fulfilled.

Data Normality Test with Determinant of Sample Covariance Matrix, which is to see whether there are multicollinearity and singularity in a combination of variables. Really small determinants indicate the presence of multicollinearity or singularity. (Kline, 2011)Itis hoped that the Determinant of Sample Covariance Matrix will avoid ZERO and better if $>$ 1. The results show the Determinant of Sample Covariance Matrix 7.398 thus the assumption of multicollinearity in this study has been fulfilled.

Based on path analysis, the following are presented path coefficients of the standardized structural equation of this study

\begin{tabular}{cccccc}
\multicolumn{6}{c}{ Table 4 Coefficients of the Standardized } \\
\hline $\begin{array}{c}\text { Combined } \\
\text { Variable }\end{array}$ & $\begin{array}{c}\text { Direc- } \\
\text { tion } \\
\text { Hypo- } \\
\text { thesis }\end{array}$ & $\begin{array}{c}\text { Coef. } \\
\text { Esti- } \\
\text { mated }\end{array}$ & S.E & P & $\begin{array}{c}\text { Accepted/ } \\
\text { Rejected }\end{array}$ \\
\hline $\begin{array}{c}\text { Bank Size (X1) } \\
\Rightarrow>\text { BOPO (Y1) }\end{array}$ & - & $-0,415$ & 0,168 & 0,000 & Accepted \\
\hline
\end{tabular}

\begin{tabular}{lccccc}
\hline $\begin{array}{l}\text { Bank Size (X1) } \\
=>\text { ROA (Y2) }\end{array}$ & + & 0,048 & 0,119 & 0,347 & Rejected \\
\hline $\begin{array}{l}\text { BOPO (Y1) } \\
=>\text { ROA (Y2) }\end{array}$ & - & 0,751 & 0,006 & 0,000 & Accepted \\
\hline Source: Processed Data (2019) &
\end{tabular}

The estimated results of the coefficients standardized in table 2 above show the following conditions:

1. Bank Size (X1) has a negative influence and is significant for BOPO (Y1). This indicates that the bigger the size of the bank the BOPO value will be smaller or the bank will be more efficient.

2. Bank Size (X1) has a positive and not significant effect on ROA (Y2). This shows that the bank size has less influence on the profitability of a bank.

3. BOPO (Y1) has a negative and significant effect on profitability (Y2). This confirms that when a high bank BOPO ratio (inefficient) will reduce the ability of banks to obtain profitability.

\section{Indirect Calculation}

Calculation of indirect effects is done by multiplying the value of each variable, which can be seen in table 5 below

\begin{tabular}{ccc}
\multicolumn{3}{c}{ Table 5 Indirect Effects } \\
\hline $\begin{array}{c}\text { Combined } \\
\text { Variable }\end{array}$ & $\begin{array}{c}\text { Effect to Y1 x } \\
\text { Coef. Direct Ef- } \\
\text { fects To Y1 To Y2 }\end{array}$ & $\begin{array}{c}\text { Coefficient Indi- } \\
\text { rect Effects }\end{array}$ \\
\hline $\mathrm{X} 1$ => Y2 Via Y1 & $-0,415 \times$ - 0,751 & 0,312 \\
\hline Source: Processed Data (2019)
\end{tabular}

Based on the results of calculations in table 4, the results of the combination of Bank Size variables à bank profitability via Bank bank Efficiency (BOPO) have a weighting value of 0.312 . This shows that Bank Size has a positive relationship and tends to increase bank profitability by increasing bank efficiency.

Calculation of the Total Effect

Calculation of the total effect by summing the values of each variable, as can be seen in table 5 below: 
Tabel 6 Total Effect

\begin{tabular}{ccc}
\hline $\begin{array}{c}\text { Combined } \\
\text { Variable }\end{array}$ & $\begin{array}{c}\text { Coefficient Direct } \\
\text { Effects to Y2 }+ \\
\text { Coef. Indirect } \\
\text { Effect Y2 }\end{array}$ & $\begin{array}{c}\text { Coefficient Total } \\
\text { Effect }\end{array}$ \\
\hline $\mathrm{X} 1=>$ Y2 Via Y1 & $0,048+0,312$ & 0,360 \\
\hline Source: Processed Data (2019)
\end{tabular}

Based on the calculation of the total effect in table 5, the effect of bank size on profitability (ROA) via bank efficiency (BOPO) has a weight of 0.360 . These results indicate that bank size variables have a positive influence on bank profitability via bank efficiency (BOPO). This shows the greater the size of the company or bank, the greater the chance of the bank to obtain large profits by managing assets and achieving good bank efficiency.

Calculation of Significance Value Influence Mediation (Sobel Test)

To test the significance value of mediating variables, in addition to using the Sobel test can also be done with Hayes, OLS, and Preacher. In research using tools software, AMOSthat cannot directly test the role of mediation, mediation testing in variables in the study can be done using the Sobel test. The calculation of the significant value of the mediation effect in this study is carried out by a Sobel test which aims to obtain the significance value of the role of the intermediary variable in a model. The significant value of the role of intermediary variables calculated by multiplying the estimated value (estimate)and standard error (SE), Sobel, (1982), (Tangke $P, 2018$ )

Table 7 below are the results of the calculation of the role of intermediary variables of this research model.

\begin{tabular}{cccc}
\multicolumn{4}{c}{ Table 7 Mediation effect } \\
$\begin{array}{ccc}\text { Combined } \\
\text { Variable }\end{array}$ & $\begin{array}{c}\text { Value } \\
\text { Estimated }\end{array}$ & $\begin{array}{c}\text { Standar } \\
\text { Error }\end{array}$ & $\begin{array}{c}\text { P Value of } \\
\text { Sobel Test }\end{array}$ \\
\hline X1 => & $-0,415 ;$ & 0,$168 ;$ & 0.0135 \\
Y2 Via Y1 & $-0,751$ & 0,006 & \\
\hline
\end{tabular}

Source: Calculation with the statistic calculator version 3.1 Beta (2019)

Based on calculations Sobel test in Table 6 above, it can be explained that the effect of indirect costs on the profitability of banks through the promotion of market share in deposits has a value of P-Value Sobel test of $0.0135<$ alpha 0.05

\section{Hypothesis Testing}

Hypothesistesting is done by comparing the $\mathrm{p}$-value with a significance level (alpha) of 0.05. If p-value < alpha 0.05 then $\mathrm{Ho}$ is rejected and $\mathrm{H} 1$ is accepted. Conversely, if p-value > alpha 0.05, then Ho is accepted and $\mathrm{H} 1$ is rejected. The results of testing the hypothesis in this study are summarized in the following table:

Table 8 Results of Testing Hypotheses

\begin{tabular}{lcc}
\hline $\begin{array}{c}\text { Combined } \\
\text { Variable }\end{array}$ & $\begin{array}{c}\text { P } \\
\text { Value }\end{array}$ & $\begin{array}{c}\text { Accepted } \\
\text { Rejected }\end{array}$ \\
\hline Bank Size $(\mathrm{X} 1=>$ BOPO $(\mathrm{Y} 1)$ & 0,000 & Accepted \\
\hline Bank Size $(\mathrm{X} 1)=>$ ROA $(\mathrm{Y} 2)$ & 0,347 & Rejected \\
\hline BOPO (Y1) => ROA (Y2) & 0,000 & Accepted \\
\hline Bank Size $(\mathrm{X} 1)=>$ ROA (Y2) Via BOPO (Y1) & 0,013 & Accepted \\
\hline Source: Processed Data (2019) &
\end{tabular}

\section{Hypothesis Testing 1}

Based on the results of the path analysis in table 2 above, the coefficient standardized beta of Bank Size (X1) direct influence on BOPO (Y1) is -0.415 with a p-value of $0.000<$ alpha 0.05 . This shows that Bank Size has a negative and significant effect on BOPO (Y1).

Thus the H1 Hypothesis stating that the Bank Size has a direct influence on the efficiency of bank banks (BOPO) is acceptable.

\section{Testing of Hypothesis 2}

Based on the results of the path analysis in table 2 above, the coefficient standardized beta of Bank Size (X1) direct influence on ROA (Y2) is 0.048 with a p-value of 0.347> alpha 0.05. This shows that Bank Size has a positive and 
not significant direct effect on ROA (Y2).

Thus Hypothesis $\mathrm{H} 2$ which states that Bank Size has a direct influence on bank profitability (ROA) is rejected.

\section{Hypothesis Testing 3}

Based on the results of path analysis in table 2 above, the coefficient value of standardized beta the direct effect of BOPO (Y1) on profitability ROA (Y2) is -0.751 with a p-value of $0,000<$ alpha 0.05. This shows that BOPO has a negative and significant effect on bank profitability.

Thus the $\mathrm{H}_{3}$ hypothesis which states that $\mathrm{BOPO}$ has a direct influence on bank profitability is acceptable.

\section{Hypothesis Testing 4}

Based on the results of the analysis of indirect effects in table 5 and the calculation of the double significance value test in table 7 above, the coefficient of bank size (X1) indirect effect on profitability of ROA (Y2) bank efficiency $\mathrm{BOPO}(\mathrm{Y} 1)$ is 0.312 with value p-value of 0.013 < alpha 0.05. This indicates that bank size has an indirect influence on bank profitability. Or in other words, the efficiency of banks is able to mediate the effect of bank size on bank profitability.

Thus the $\mathrm{H}_{4}$ hypothesis which states that bank size has an indirect influence on bank profitability through bank efficiency is acceptable.

\section{DISCUSSION}

The Direct Effect of Bank Size on Bank Efficiency

The results of testing Hypothesis 1 (H1) indicate that Bank Size has a direct influence on the efficiency of bank banks (BOPO). The results of this study are in line with the research of Perwitaningtyas \& Pangestuti, (2015) which found that the greater the size of the bank, the more efficient it will be. Another study from (Yusniar, 2011), Banna et al., (2017) found that with a large company size banks will be able to achieve optimal operational efficiency.

With large asset ownership consisting of various kinds of productive assets, the bank will benefit greatly. Furthermore, if the size of the bank is positively related to market power, the larger sized bank input costs will be lower, and allow for a situation where the input/output ratio decreases with the increase in the company.

\section{Bank Size Direct Effects on Bank Profitability}

The results of testing Hypothesis 2 (H2) indicate that bank size has a positive but not significant effect on bank profitability. The results of this study are in line with (Petria et al., 2015), (Martins et al., 2019), (Bouzgarrou et al., 2017), (Vernanda \& Widyarti, 2016) found that size did not significantly influence bank profitability. However, different research results obtained by Kosmidou \& Zopounidis (2008) and Menicucci \& Paolucci (2016) found that bank size is one of the determinants of bank profitability.

The results of the study showed a positive but not significant effect due to many other factors that could affect profitability. bank. These factors consist of external factors that are beyond the control of the bank such as macroeconomic variables and internal bank factors such as asset management that is less effective.

The Effect of Efficiency on Bank Profitability

The results of testing Hypothesis 3 ( $\left.\mathrm{H}_{3}\right)$ indicate that bank efficiency has a negative and significant effect on bank profitability. The same results were obtained from research (Vernanda \& Widyarti, 2016) (Petria et al., 2015), (Martins et al., 2019) found that BOPO had a negative and significant effect on bank profitability. This shows that when the bank is unable to suppress the BOPO 
ratio as small as possible it will have an impact on the bank's profitability. By pressing input or lower costs the bank will get greater profitability.

\section{Bank Size Indirect Effects on Bank Profitability Through Bank Efficiency}

The results of testing Hypothesis 4 (H4) indicate that Bank size has a positive and significant indirect effect on bank profitability through bank efficiency. This shows that the efficiency of banks is able to mediate the effect of bank size on bank profitability. With the size of the company marked by large asset ownership, the bank will get high profitability if the assets owned by the bank are managed properly and efficiently.

\section{CONCLUSION}

From this study the conclusions can be drawn as follows:

1. Bank Size has a direct influence on the efficiency of bank banks. Larger banks will have lower input costs and allow a situation where the input/output ratio decreases with increasing companies.

2. Bank size has a positive but not significant effect on bank profitability. Large asset ownership when not managed properly will increase problematic productive assets which will have an impact on the decline in bank profitability.

3. The efficiency of banks has a significant influence on bank profitability. When a bank is able to reduce the bank's BOPO ratio it will be able to increase profitability. By pressing input or lower costs the bank will get greater profitability.

4. Bank size has a positive and significant influence on bank profitability through bank efficiency. This shows that the efficiency of banks is able to mediate the effect of bank size on bank profitability.

\section{REFERENCES}

Adelopo, I., Lloydking, R., \& Tauringana, V. (2018). Determinants of bank profitability before, during, and after the financial crisis. International Journal of Managerial Finance, 14(4), 378-398. https:// doi.org/10.1108/IJMF-07-20170148

Bank Indonesia. (2019). Statistik Sistem Keuangan Indonesia SSKI.

Banna, H., Ahmad, R., \& Koh, E. H. Y. (2017). Determinants of Commercial Banks' Efficiency in Bangladesh: Does Crisis Matter? The Journal of Asian Finance, Economics and Business, 4(3), 19-26. https://doi.org/10.13106/ jafeb.2017.vol4.no3.19

Bouzgarrou, H., Jouida, S., \& Louhichi, W. (2017). Bank Profitability During and Before the Financial Crisis : Domestic vs . Foreign Banks *. Research in International Business and Finance. https://doi. org/10.1016/j.ribaf.2017.05.011

Dendawijaya, L. (2003). Manajemen Perbankan (Edisi Kedu). Jakarta: PT. Galia Indonesia.

Ghozali. (2013). Aplikasi Analisis Multivariate Dengan Program IBM SPSS 21, Up Date PLS Regresi (7th ed.). Semarang: Badan Penerbit Universias Diponegoro.

Gunawan., A., \& Sudaryanto, B. (2016). Analisis Pengaruh Performance , Size, Inefisiensi , Capital, Dan Dana Pihak Ketiga Terhadap Non Performing Loan. DIPONEGORO JOURNAL OF MANAGEMENT, Vol. 5, 1-13. 
Kline, R. (2011). Principle and Practice of Structural Equation Modeling (3rd ed.). New York: The Guildford Press.

Kosmidou, K., \& Zopounidis, C. (2008). Measurement of Bank Performance in Greece. South-Eastern Europe Journal of Economics C. ZOPOUNIDIS South-Eastern Europe Journal of Economics, 1(1), 79-95.

Martins, A. M., Serra, A. P., \& Stevenson, S. (2019). Determinants of real estate bank profitability. Research in International Business and Finance, 49, 282-30o. https://doi. org/10.1016/j.ribaf.2019.04.004

Marwansyah, S., \& Setyaningsih, E. D. (2018). Pengaruh Kinerja Perbankan Terhadap Rasio Profitabilitas Pada Bank BUMN. Jurnal Akuntansi, Ekonomi Dan Manajemen Bisnis, 6(1), 11-18.

Menicucci, E., \& Paolucci, G. (2016). The determinants of bank profitability : empirical evidence from European banking sector. Journal of Financial Reporting and Accounting, Vol. 14(No. 1), pp 86-115.

Otoritas Jasa Keuangan. (2018). Statistik Perbankan Indonesia SPI.

Perwitaningtyas, G. A., \& Pangestuti, I. R. D. (2015). Faktor-Faktor Yang Mempengaruhi Efisiensi Bank Di Indonesia Periode Tahun 20082012. Diponegoro Journal Of Management, 4(1), 1-14.

Petria, N., Capraru, B., \& Ihnatov, I. (2015). Determinants of Banks' Profitability: Evidence from EU 27 Banking Systems. Procedia
Economics and Finance, 20(15), 518-524. https://doi.org/10.1016/ s2212-5671(15)00104-5

Rima Yunita. (2014). Faktor-Faktor yang Mempengaruhi Tingkat Profitabilitas Perbankan Syariah di Indonesia. Jurnal Akuntansi Indonesia, 3(2), 143-160.

Tangke P. (2018). Pengaruh Political Connection, Specific Asset, Financial Leverage Dan Foreiign Ownership Terhadap Corporate Sustainability Melalui Corporate Governance. Disertasi, Universitas Hasanuddin, 123.

Van Horne dan Wachowicz. (2005). Analisis Roa Dan Roe Terhadap Profitabilitas Bank Di Bursa Efek Indonesia. Al-Masraf : Jurnal Lembaga Keuangan Dan Perbankan, 1(2), 222.

Vernanda, S. D., \& Widyarti, E. T. (2016). ANALISIS PENGARUH CAR, LDR, NPL, BOPO, DAN SIZE TERHADAP ROA (Studi pada Bank Umum Konvensional yang Terdaftar di Bursa Efek Indonesia Periode 20102015). DIPONEGORO JOURNAL OF MANAGEMENT, Vol 5, 1-13. Retrieved from http://ejournal-s1. undip.ac.id/index.php/dbr

Yusniar, M. W. (2011). Analisis Efisiensi Industri Perbankan di Indonesia Dengan Pendekatan Data En- velopment Analysis ( Dea ) Dan Faktor .. Faktor Yang Mempengaruhinya. Jurnal Manajemen \& Bisnis, 1(2), 175-195. 